\title{
Studies of dissolved carbohydrates (or carbohydrate-like substances) in an estuarine environment*
}

ARTICLE · JANUARY 1991

READS

11

1 AUTHOR:

\section{William Senior}

Universidad Estatal de la Península de Santa...

78 PUBLICATIONS 153 CITATIONS

SEE PROFILE 


\title{
Studies of dissolved carbohydrates (or carbohydrate-like substances) in an estuarine environment*
}

\author{
William Senior ${ }^{* *}$ and-Lionel Chevolot ${ }^{* * *}$ \\ Laboratoire d'Océanographie Chimique, URA CNRS 322, Université de Bretagne Occidentale, 6 , \\ avenue le Gorgeu, 29287 Brest Cedex (France)
}

(Received February 13, 1989; revision accepted May 28, 1990)

\begin{abstract}
Senior, W. and Chevolot, L., 1991. Studies of dissolved carbohydrates (or carbohydrate-like substances) in an estuarine environment. Mar. Chem., 32: 19-35.

Variations in concentrations of dissolved sugars were studied along the salinity gradient of a small estuary (Elorn, Bay of Brest, France) from February 1985 to January 1986. Total dissolved carbohydrate (TDCHO) and dissolved monosaccharides (MCHO) were measured by the methods of Burney and Sieburth and Johnson and Sieburth respectively. It must be noted that these methods cannot distinguish between carbohydrates and carbohydrate-like substances; consequently, these methods probably do not closely reflect biologically available pools of carbohydrates. In the river, TDCHO and $\mathrm{MCHO}$ values ranged from 230 to $970 \mu \mathrm{g} \mathrm{Cl}^{-1}$ and from 75 to $450 \mu \mathrm{g} \mathrm{C} \mathrm{l^{-1 }}$ respectively. In the estuary, TDCHO and MCHO were usually lower; they varied respectively from 20 to $570 \mu \mathrm{g} \mathrm{Cl}^{-1}$ and from 0 to $180 \mu \mathrm{g} \mathrm{Cl}^{-1}$. In June, some TDCHO values were much higher, probably because some polysaccharide was produced at this time by phytoplankton excretion or lysis.

The relationship between $\mathrm{Cl} \%$ and TDCHO was dependent on the seasons. TDCHO was conservative in autumn, winter and early spring. TDCHO and DOC concentrations were fairly well correlated during the same period. Similar results have been previously reported by various workers. MCHO and TDCHO concentrations were well correlated throughout this study except in June. From these results, it was concluded that most dissolved carbohydrates were linked to a conservative fraction of the organic matter in periods of low biological activity, whereas newly biosynthesised carbohydrates were responsible for non-conservative behaviour.
\end{abstract}

\section{INTRODUCTION}

There is a growing interest in the study of dissolved organic matter (DOM) in seawater as it becomes increasingly obvious that DOM interacts with many biological and chemical phenomena.

\footnotetext{
*This paper forms part of the thesis (Thèse de Doctorat) of W. Senior.

**Present address: Nucleo de Sucre, Instituto Oceanografico Universidad de Oriente, AP 245, Cerro Colorado, Cumana, Venezuela.

***Author to whom correspondence should be addressed at: Laboratoire de Biologie Marine, Universite de Nantes, 2 rue de la Houssinière, 44072 Nantes, France.
} 
Although carbohydrates are important constituents of DOM (usually $10-$ $20 \%$ ), relatively little is known about them, especially in estuarine and coastal ecosystems, mainly because analytical techniques cannot be used in routine work. Some methods have been used to determine either the total carbohydrate content or the monomeric sugar composition of seawater, but these methods are difficult and time consuming. (Further information is given in the following reviews: Mopper (1980), Dawson and Liebezeit (1981a,b) and Liebezeit and Dawson (1982).)

Sugars, in the total dissolved carbohydrate (TDCHO) pool, are present as monosaccharides (MCHO) or polysaccharides ( $\mathrm{PCHO}$ ); the latter should be divided between biogenic polysaccharides and carbohydrates bound to humic substances (HS). However, it is not easy to distinguish between these last fractions and they are usually measured together as $\mathrm{PCHO}$.

From the data collected in various earlier studies, the following features appear:

(1) TDCHO and MCHO concentrations vary, in seawaters and brackish waters, from 30 to $1300 \mu \mathrm{g} \mathrm{C} 1^{-1}$ and from 2 to $300 \mu \mathrm{g} \mathrm{C} 1^{-1}$ respectively. A few higher values have also been reported (Sumitra et al., 1972).

(2) The MCHO fraction usually accounts for a significant part of TDCHO (Burney and Sieburth, 1977; Ittekkot et al., 1981; Sakugawa and Handa, 1985); sometimes for more than half (Burney et al., 1979; Harvey, 1983).

(3) Diurnal fluctuations of TDCHO may occur in periods of biological activity (Walsh, 1965; Burney et a1., 1981a,b); Harvey, 1983; Eberlein et al., 1983 ), but the MCHO concentrations are fairly constant over a 24 -h period (Burney et al., 1981a,b; Burney, 1986a).

(4) In only a few studies have attempts been made to establish a relationship between sugar composition and other chemical, physical and biological parameters.

We report here results obtained from a study performed in a small estuary located in Brittany (Elorn Estuary, Bay of Brest, France; see Fig. 1.). Some preliminary results have been published elsewhere (Senior et al., 1987). To our knowledge, this is one of the few studies performed over such a long period of time in the same area. Seasonal variations and origins are studied; the nature of dissolved carbohydrates is discussed in the light of present and published data.

METHODS AND MATERIAL

Study area

Figure 1 shows the Elorn Estuary (Brittany, France) and the location of the seven sampling sites. Sites $\mathrm{E}_{1}$ and $\mathrm{E}_{2}$ are low-salinity sites, and they are 


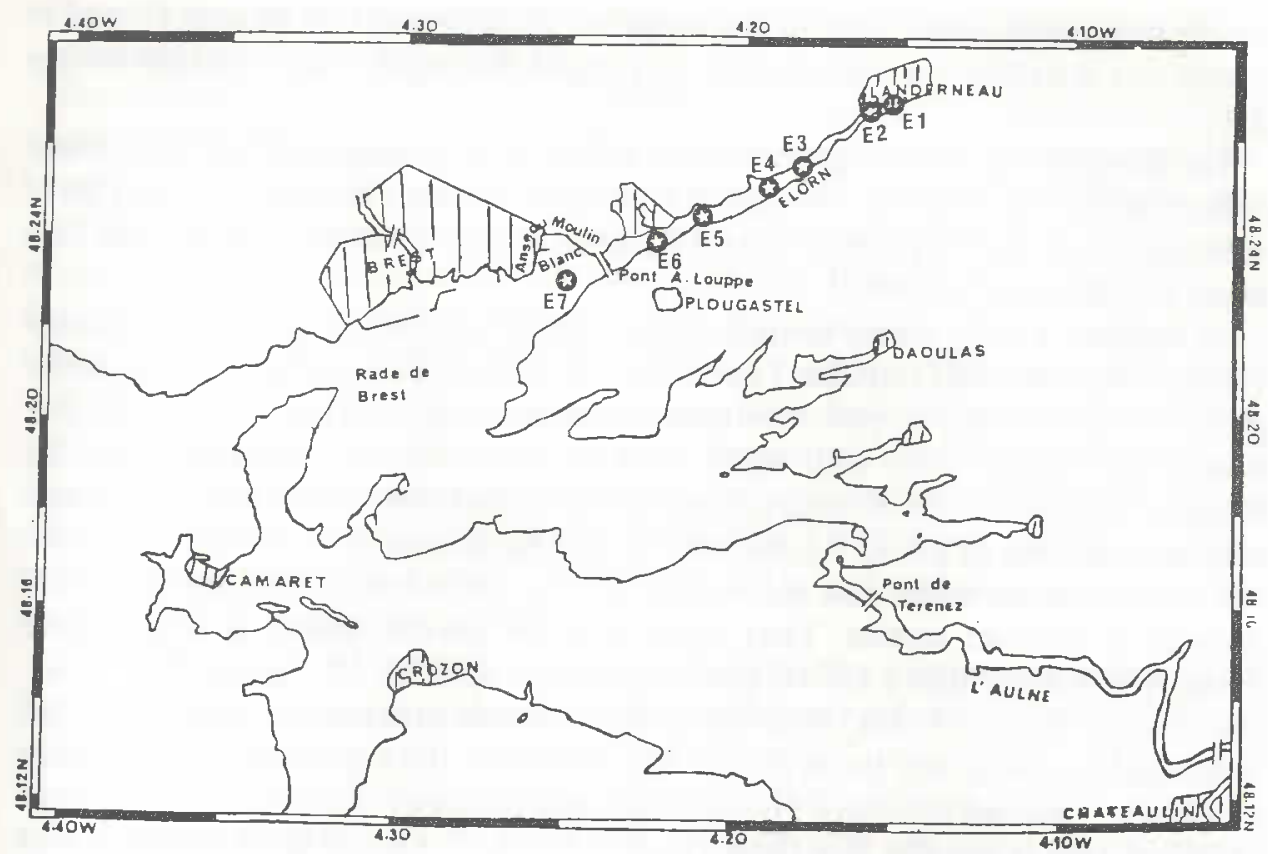

Fig. 1. Location of sampling sites in the Elorn Estuary.

considered to be located in the river. Elorn is a $12-\mathrm{km}$-long estuary. The depth ranges from $3.5 \mathrm{~m}$ at Landerneau to $12.5 \mathrm{~m}$ at Albert Louppe bridge.

During this study, the flow of the river varied between 1.3 and $18 \mathrm{~m}^{3} \mathrm{~s}^{-1}$. A detailed record has been published earlier (Noureddin et al., 1987), together with the rainfall record. This estuary is strongly influenced by tide patterns; the renewal time of the water is between 2 and 4 days (L'Yavanc, 1984). Landerneau (see Fig. 1) is a medium-sized city of 20000 inhabitants. Two sewers discharge Landerneau's waste-water, after cleaning by a sewage-treatment system, slightly downstream from site $\mathrm{E}_{2}$ (mean accumulated flux: 5000 $\mathrm{m}^{3} \mathrm{day}^{-1}$, mean $\mathrm{DOC}$ value $20 \mathrm{mg} \mathrm{C}^{-1}$ ). In the same area (between sites $\mathrm{E}_{2}$ and $E_{3}$ ) there is also a seaweed-processing factory which extracts alginate from brown seaweeds $\left(30000 \mathrm{t} \mathrm{year}^{-1}\right)$. Waste-water from this factory is discharged into the estuary in an erratic manner. Site $E_{3}$ is about $3 \mathrm{~km}$ downstream from this plant. In addition, upstream from site $E_{1}$, there is also a milk-processing factory, but its waste-water is treated. Lastly, at downstream sites $E_{6}$ and $E_{7}$, some organic matter may come from the main sewer that collects Brest waste-water which is discharged (after treatment) close to Moulin Blanc Bay (see Fig. 1).

\section{Sampling}

Water samples were collected from February 11, 1985, to January 8, 1986 (see Table 1). Samples were collected during the $2-3$-h period around high 
water; tide coefficients were in the range of 70-80 except on March 11 (98). It was not possible, for each cruise, to sample during the same period of the day.

The samples can also be grouped according to the season in which they were collected: spring (March 11-June 7) or early spring (March 11-April 24), summer (July and September) and autumn-winter (February 1985 and October 11-January 8, 1986).

At stations $E_{3}-E_{7}$, water sampling was carried out using an electrical pump (Lenze Discovertell Getriebe Type 11602, F.R.G.). This pump is a peristaltic pump with a synthetic polymer tube; consequently, there is no contact between mechanical parts and water, and no possibility of contamination by biogenic molecules; DOC measurements have also shown that there is no significant increase of DOC. At stations $\mathrm{E}_{1}$ and $\mathrm{E}_{2}$, a clean glass bottle was used. All samples were taken just below the surface and were filtered immediately through a $100-\mu \mathrm{m}$ screen. They were kept for several hours at $5^{\circ} \mathrm{C}$ before being filtered through a GF/C precombusted $\left(450^{\circ} \mathrm{C}, 4 \mathrm{~h}\right)$ glass fiber filter. For the few hours (3-4 h) between collection and processing, some bacterial degradation could not be avoided, but from the data published by Burney (1986a,b), we can estimate (in summer and in dark) that the TDCHO degradation rate is usually less than $10 \mu \mathrm{g} \mathrm{C}^{-1} \mathrm{~h}^{-1}$. Ochiai et al. (1980) and Ochiai and Nakajima (1985) gave similar or lower decomposition rates in freshwater. At $5^{\circ} \mathrm{C}$, the loss is probably less. Error introduced by keeping the water for a few hours did exist, but was of the same magnitude as the experimental analytical error (see analytical methods). For MCHO, bacterial utilization (for the same period) was probably significant. On the other hand, filtering with $\mathrm{GF} / \mathrm{C}$ only partially removed bacteria. Consequently, some carbohydrates counted as TDCHO were indeed bacterial particulate carbohydrates, but probably only to a slight extent, because we also analysed $36 \mathrm{sam}$ ples by HPLC and found bacterial sugars (rhamnose, fucose, ribose) only at low percentages (Senior, 1986). Filtrates were then kept in glass bottles after addition of $1 \mathrm{ml} \mathrm{l}^{-1}$ of a saturated $\mathrm{HgCl}_{2}$ solution. All glassware used throughout the analysis was precombusted $\left(450^{\circ} \mathrm{C}\right.$, overnight $)$.

\section{Analytical methods}

Analyses of DOC were carried out on a Dohrmann DC 80 analyser which performs photo-oxidation of samples in the presence of persulfate. Results

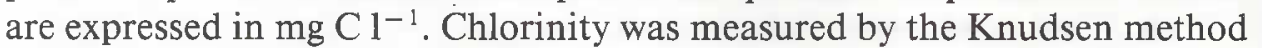
according to the procedure described by Aminot (1983). Chlorophyll $a$ and phaeophytin $a$ were determined fluorometrically using a Turner III fluorometer, according to Lorenzen (1967), after extraction from the filters by an acetone-water mixture $(90: 10, \mathrm{v} / \mathrm{v})$. However, we should point out that re- 
sults obtained by this method may not be accurate for estuarine environments (Mantoura and Llewellyn, 1983).

For dissolved monosaccharides (MCHO), the method of Johnson and Sieburth (1977) was used, following the procedure given by Dawson and Liebezeit (1981a,b). Mannitol and glucose were used as standards. Molar concentrations were calculated from the control corrected mean absorbance data using the (glucose + mannitol) $/ 2$ regression line. Results are expressed in $\mu \mathrm{g}$ $\mathrm{C}^{-1}$ of glucose equivalent. In our hands, the precision of this method was not as high as stated by Dawson and Liebezeit (1981b). Measures were made in triplicate (three aliquots from the same sample bottle); standard deviation varied from 10 to $30 \mu \mathrm{g} \mathrm{Cl}^{-1}$ depending on the sample. Obviously, this method cannot distinguish between true monosaccharides and any substances which possess a terminal glycol function $\left(\mathrm{CHOH}-\mathrm{CH}_{2} \mathrm{OH}\right)$. Such a function is expected to be present in humic substances (HS), and consequently, interference with them cannot be avoided.

For total dissolved carbohydrates (TDCHO), the method of Burney and Sieburth (1977) was used. However, the conditions of hydrolysis were different (Ittekkot, 1982): 5-ml seawater samples with $1 \mathrm{ml}$ of $\mathrm{HCl}(30 \%)$ were hydrolysed at $100^{\circ} \mathrm{C}$ for $3.5 \mathrm{~h}$. After cooling, the acid was neutralized with concentrated $\mathrm{NaOH}(\sim 1 \mathrm{ml})$. $\mathrm{pH}$ was checked with $\mathrm{pH}$ papers. Concentrations were corrected for dilutions. As for MCHO, HS interference occurs. However, a good correlation $(r=0.97, n=36$; slope $=1.1)$ was obtained between the sum of individual sugars measured by HPLC (see above; Senior, 1986 ) and the result given by the MBTH method.

The concentration of dissolved polysaccharides $(\mathrm{PCHO})$ is the difference between the concentration in TDCHO and the concentration in MCHO (Burney and Sieburth, 1977).

\section{RESULTS AND DISCUSSION}

Tables 1 and 2 list respectively the TDCHO and $\mathrm{MCHO}$ concentrations at each site during the period studied. The TDCHO concentrations were variable in the river and ranged from 230 to $970 \mu \mathrm{C}^{-1}$. This variability could be cansed by some material being brought by tidal currents (sampling was periornad at bigh water ; from Landerneau's sewers or from the seaweed fac-

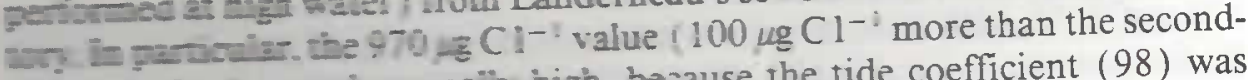
angel was ahoormally high, because the tide coefficient (98) was

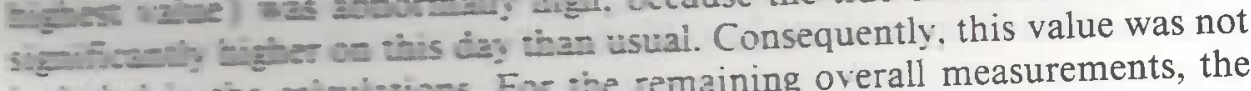
included is :he calculations. For the remaining overall measurements, the mean value was $560 \mathrm{\mu g} \mathrm{Cl}^{-1}$. In aurumr-winter, the average concentration in the river was higher $\left.(675 \mu \mathrm{g} \mathrm{C})^{-1}\right)$ than in early spring $\left(420 \mu \mathrm{g} \mathrm{C}^{-1}\right)$. At downstream stations. the TDCHO concentrations were usually lower (20- 
TABLE 1

TDCHO concentrations $\left(\mu \mathrm{g} \mathrm{Cl} 1^{-1}\right)$ in the Elorn Estuary

\begin{tabular}{|c|c|c|c|c|c|c|c|}
\hline \multirow[t]{2}{*}{ Date (1985) } & \multicolumn{7}{|l|}{ Site } \\
\hline & $\mathrm{E}_{1}$ & $\mathrm{E}_{2}$ & $\mathrm{E}_{3}$ & $E_{4}$ & $\mathrm{E}_{5}$ & $\mathrm{E}_{6}$ & $\mathrm{E}_{7}$ \\
\hline February 11 & 860 & 530 & 350 & 340 & 140 & 40 & 20 \\
\hline March 11 & $970^{*}$ & 440 & 145 & 180 & 155 & 150 & 125 \\
\hline April 3 & 320 & 430 & 310 & 265 & 220 & 240 & 290 \\
\hline April 17 & 495 & 750 & 230 & 205 & 280 & 255 & 245 \\
\hline April 24 & 265 & 265 & 210 & 105 & 165 & 145 & 140 \\
\hline June 7 & 795 & 785 & 620 & 755 & 470 & 1080 & 395 \\
\hline July 1 & 550 & 480 & 325 & 185 & 270 & 265 & 165 \\
\hline September 20 & 305 & 230 & 395 & 385 & 320 & 195 & 205 \\
\hline October 11 & 765 & 755 & 330 & 295 & 295 & 305 & 215 \\
\hline November 25 & 545 & 835 & 120 & 115 & 145 & 90 & 100 \\
\hline December 9 & 700 & 715 & 400 & 315 & 295 & 265 & 245 \\
\hline January 8 (1986) & 500 & 545 & 570 & 325 & 315 & 250 & 240 \\
\hline
\end{tabular}

${ }^{*}$ This abnormally high value has been discarded.

TABLE 2

MCHO concentrations ( $\mu \mathrm{g} \mathrm{C}^{-1}$ ) in the Elorn Estuary

\begin{tabular}{|c|c|c|c|c|c|c|c|}
\hline \multirow[t]{2}{*}{ Date } & \multicolumn{7}{|l|}{ Site } \\
\hline & $\mathrm{E}_{\mathfrak{l}}$ & $\mathrm{E}_{2}$ & $\mathrm{E}_{3}$ & $E_{4}$ & $\mathrm{E}_{5}$ & $\mathrm{E}_{6}$ & $\mathrm{E}_{7}$ \\
\hline February 11 & 290 & 200 & 110 & 130 & 0 & 0 & 0 \\
\hline March 11 & 390 & 180 & 70 & 60 & 55 & 90 & 40 \\
\hline April 3 & 245 & 225 & 180 & 165 & 115 & 135 & 170 \\
\hline April 17 & 450 & 400 & 95 & 80 & 80 & 105 & 75 \\
\hline April 24 & 165 & 185 & 170 & 100 & 150 & 90 & 95 \\
\hline June 7 & 105 & 165 & 90 & 75 & 75 & 430 & 130 \\
\hline July 1 & 325 & 305 & 120 & 60 & 105 & 110 & 35 \\
\hline September 20 & 105 & 75 & 145 & 100 & 115 & 80 & 90 \\
\hline October 11 & 325 & 335 & 125 & 105 & 110 & 70 & 65 \\
\hline November 25 & 260 & 385 & 45 & 30 & 35 & 35 & 10 \\
\hline December 9 & 285 & 305 & 125 & 130 & 100 & 55 & 65 \\
\hline January 8 & 185 & 230 & 130 & 95 & 75 & 55 & 40 \\
\hline
\end{tabular}

$\left.570 \mu \mathrm{g} \mathrm{C}^{-1}\right)$, with some notable exceptions in June ( $1080 \mu \mathrm{g} \mathrm{Cl}^{-1}$ at station $\mathrm{E}_{6}$, for instance). The $\mathrm{MCHO}$ values were lower; they ranged from 75 to 450 $\mu \mathrm{g} \mathrm{Cl}^{-1}$ in the river and from 0 to $180 \mu \mathrm{g} \mathrm{Cl}^{-1}$ at more downstream stations.

\section{Relationship between chlorinity and TDCHO}

TDCHO concentrations showed a relatively poor but significant relationship with chlorinity $(r=0.58 ; n=83 ; P<0.001)$ for the overall measure- 
ments. If the values measured in June, July and September are not taken into account, a better relationship is obtained (see Fig. 2 a).

If the data are split into early spring values (March 11-April 24) and autumn-winter values, two different regression lines are obtained (see Fig. 2). For this last period, the $y$-intercept and slope are higher, probably because the TDCHO input from the river was more important at this time, when terrestrial plants were decaying and when the land was morements, we obtained simis worth pointing out that, without the river mes $(r=0.79 ; \quad n=20 ; \quad P<0.001$; ilar regression lines in $[\mathrm{Cl} \% 0]+390( \pm 40))$ as well as in autumn[TDCHO $]=-13.5( \pm 2.5<0.01 ;[\mathrm{TDCHO}]=-23( \pm 6.5)[\mathrm{Cl} \% 0]+600$ $( \pm 100)$ ). For both periods, $y$-intercepts ( 390 and $\left.600 \mu \mathrm{g} \mathrm{C} 1^{-1}\right)$ are acceptably close to the TDCHO mean values in the river $\left(420\right.$ and $675 \mu \mathrm{g} \mathrm{C1}^{-1}$; see above). This result suggests that the TDCHO TDCHO flux introduced into able in the river on a short time-scale, but these data also suggest that most of the estuary by the river was more stabiver and was conservative in autumnthe TDCHO was coming from the river and for this study. To our knowledge, winter and eart sime that such behaviour of dissolved carbohydrates has been this is the first this result is rather surprising, because a priori, carbohydrates establish a dynamic part of the DOM and should not be conservative.

should be a the period of higher biological activity (June-September), the DCHO vs. Cl\% relationship disappeared, probably because of some in situ production, especially in June (most of the points are above the regression line; see Fig. 2a). Surprisingly, during the early spring (Marly strong $(r=0.77 ; n=27)$, althe $\mathrm{TDCHO}$ vs. $\mathrm{Cl} \%$ relationship was evidence of biological activity in the estuary (high though there was some eviden and phaeophytin on March 11 and April 3, for concentrations in the phytoplanktonic species of the spring bloom did not exinstance ). Either the phytop the excreted carbohydrates were very quickly used crete any carbohydrates, or the excant amount of TDCHO.

Relattorship between TDCHO and phaeophytin

Durne the period of biological activity (June-September), there was a sig-

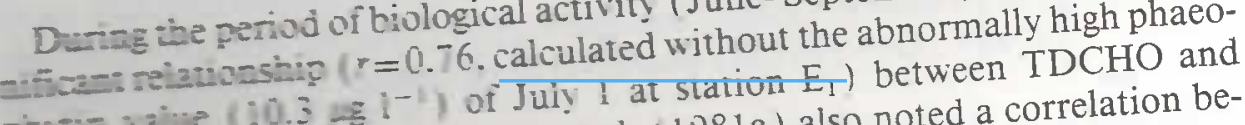

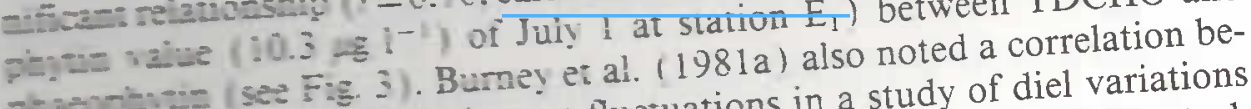

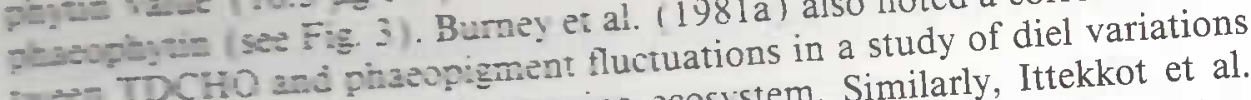
...t. TDCHO Similarly, Ittekkot et al. (igsi) dissolved combined carbohydrate concentrations towards the end of a bloom in the North Sea. According to these workers, nutrient limitation leads to the release of large amounts of carbohydrates. 

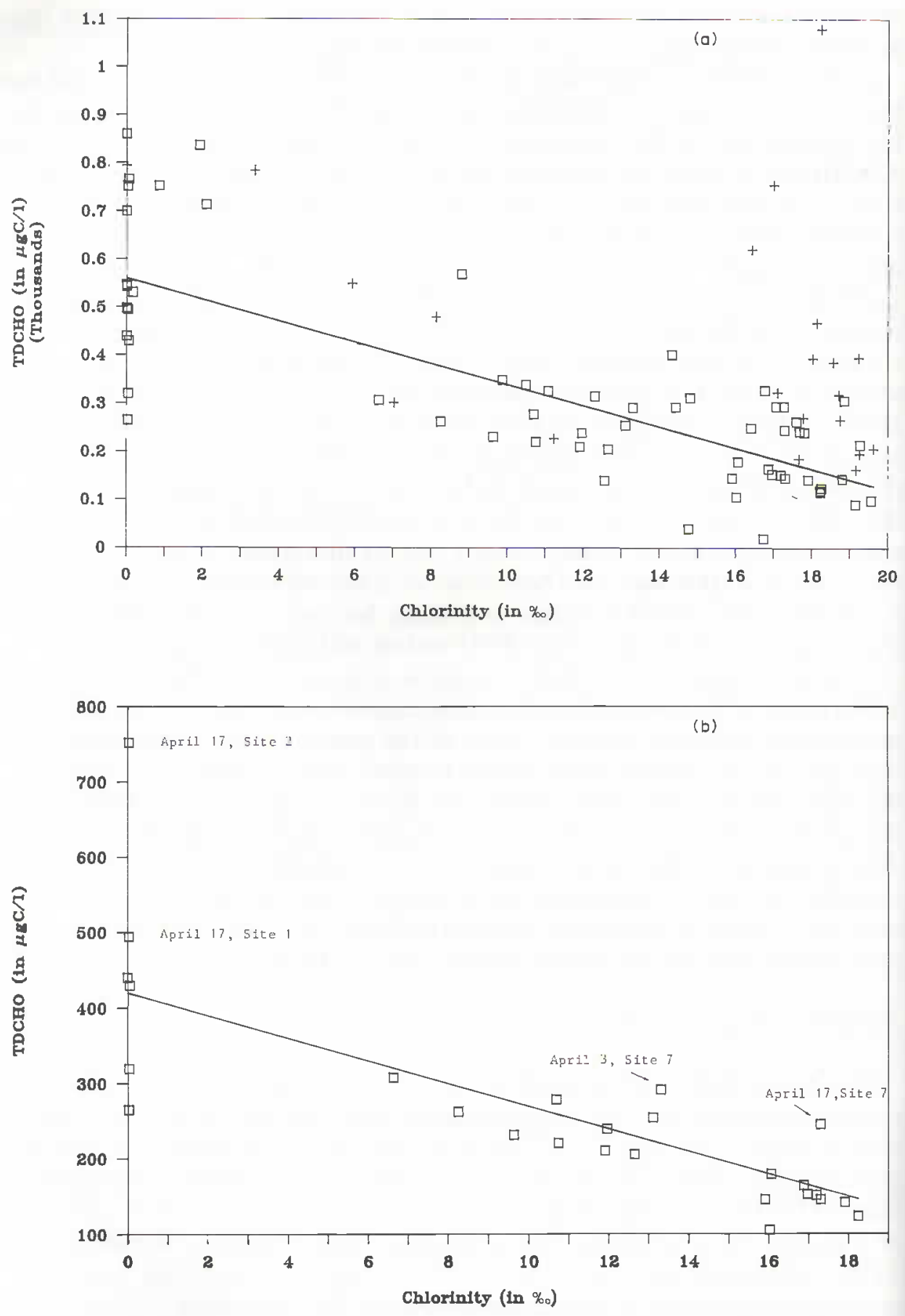


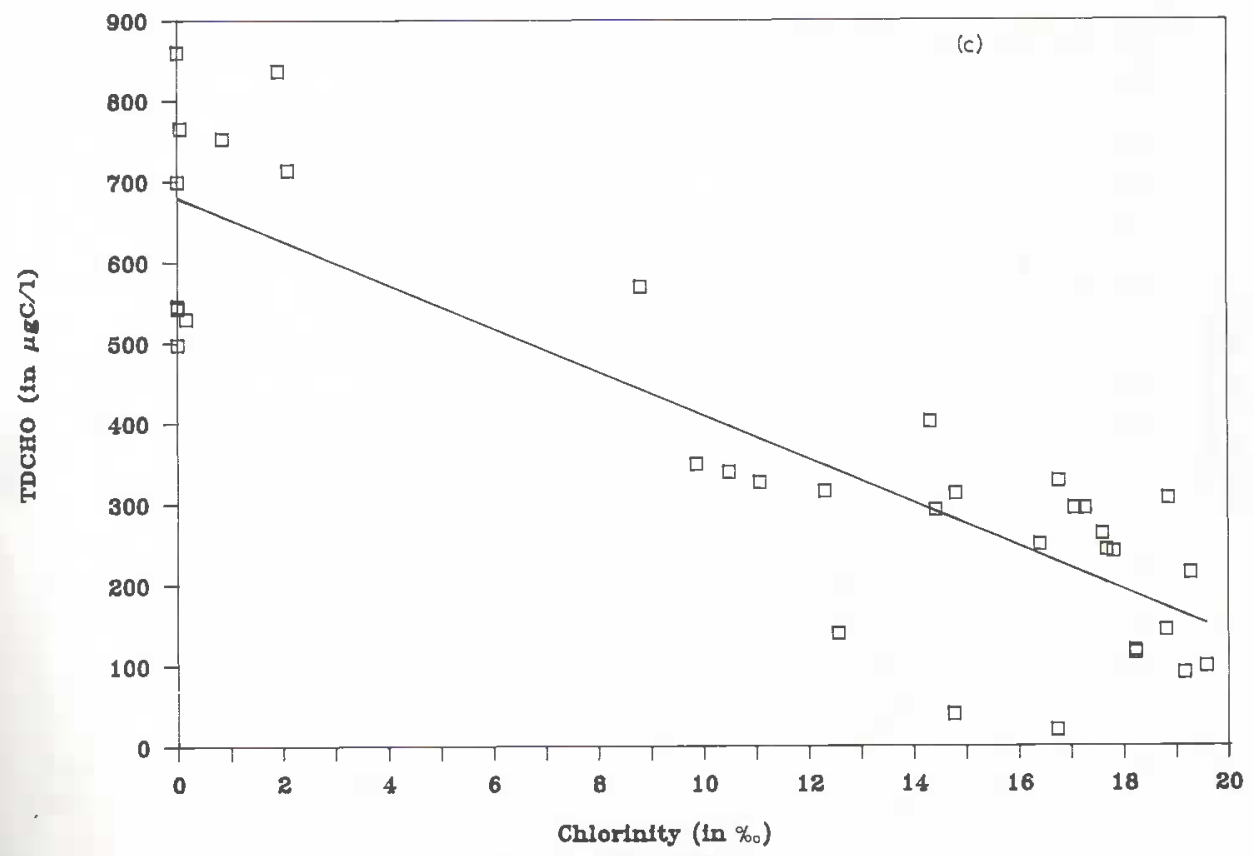

Fig. 2. The inverse relationship of TDCHO to $\mathrm{Cl} \%$. (a) For the overall measurements, the regression line was $[\mathrm{TDCHO}]=-18( \pm 3)[\mathrm{Cl} \% 0]+560( \pm 180)(r=0.58 ; n=83 ; P<0.001)$, but that shown here was calculated without the June-July-September values $(+)$ : $[\mathrm{TDCHO}]=-22( \pm 2)[\mathrm{Cl} \% 0]+560( \pm 130)(r=0.77 ; n=62 ; P<0.001)$. (b) In spring, the regression line was $[\mathrm{TDCHO}]=-15( \pm 2.5)[\mathrm{Cl} \% 0]+420( \pm 90)(r=0.77 ; n=27 ; P<0.001)$. $(\because \mathrm{i}$ in autumn-winter, the regression line was $[\mathrm{TDCHO}]=-27( \pm 2.5)[\mathrm{Cl} \%]+680( \pm 115)$ ( = $=0.87: n=35 ; P<0.001)$.

Usually, during a phytoplankton bloom, accumulation of dissolved carbohyirates is at a maximum in the stationary phase (Myklestadt, 1977; Brockmann et al., 1979). Indeed, in Fig. 2a, it is obvious that large excretions of carbohydrates occurred in the bay in summer when nutrients were depleted. For instance, nitrate fell from $20 \mu \mathrm{M} \mathrm{l}^{-1}$ in April to $4 \mu \mathrm{M}^{-1}$ in June and $0 \sim \mathrm{M}^{-:}$in July at station $\mathrm{E}_{7}$ (Senior, 1986). Consequently, during this pesod. TDCHO were not only formed by refractory carbohydrates coming from he river. but also by newly biosynthesised sugars released by senescent algal an or produced by zooplankton excretion (Burney et al., 1981a).

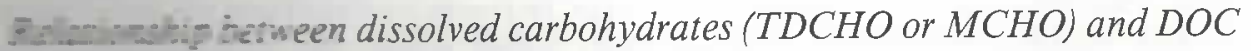

Tac TDCHO :s. DOC relationship calculated for the overall points was ata $=\dot{i}$ the rescssion line aberrant (see Fig. 4a). However, if the JuneJul. - Sep:amber : aues. together with three additional abnormally high DOC values (station $E_{5}$ of February 11. stations $E_{2}$ of December 9; station $E_{7}$ of 


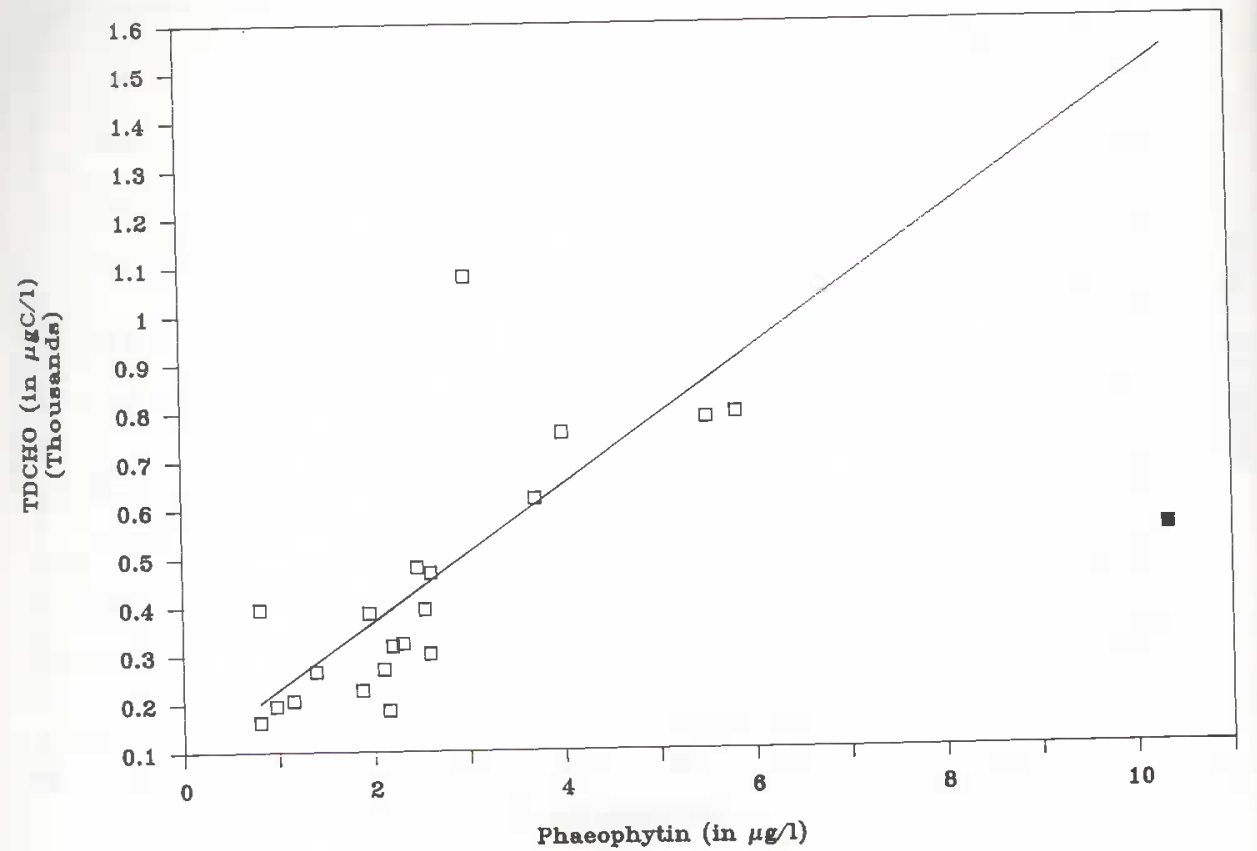

Fig. 3. The direct relationship between TDCHO and phaeophytin in June-July-September. The value for July 1 at site $E_{1}(\mathbb{Q})$ is not included in the calculation of the regression line: $[\mathrm{TDCHO}]=140( \pm 30)[$ Phaeo $]+90( \pm 170)(r=0.76 ; n=20 ; P<0.001)$.

April 3), are discarded, a much better relationship is obtained (see Fig. 4a). Very similar results have been found for MCHO. A moderately good correlation between $\mathrm{MCHO}$ and DOC may be calculated for the overall measurements $(r=0.35 ; n=84 ; P<0.01)$. The correlation coefficient is better if the same values as before are discarded $(r=0.61 ; n=60 ; P<0.001)$. The correlation becomes excellent in autumn-winter, with the exclusion of the corresponding abnormally high DOC values $(r=0.89 ; n=33 ; P<0.001$, see Fig. $4 \mathrm{~b}$ ). Consequently, in the period of low biological activity, dissolved carbohydrates (TDCHO or $\mathrm{MCHO}$ ) and DOC were correlated, and consequently had similar origins and evolutions. As the bulk of the DOM is known to be

Fig. 4. The direct relationship between dissolved carbohydrates and DOC. (a) TDCHO vs. DC relationship: the broken regression line $([\mathrm{TDCHO}]=38.5( \pm 12)[\mathrm{DOC}]+230( \pm 210)$ $r=0.33 ; n=83 ; P<0.01$ ) was calculated from overall points. The solid regression line $([\mathrm{TDCHO}]=126( \pm 13)[\mathrm{DOC}]-10( \pm 120) ; r=0.79 ; n=59 ; P<0.001)$ was calculated without the June values $(+)$ the July-September values $(\diamond)$ and three additional high DOC values $(\triangle)$. (b) $\mathrm{MCHO}$ vs. $\mathrm{DOC}$ relationship: the regression line ( $[\mathrm{MCHO}]=61( \pm 6)$ [DOC] $-55( \pm 50) ; r=0.89 ; n=33 ; P<0.001$ ) was calculated from only the autumn-winter measurements $(\square)$. $\square$ : Winter measurements not included in calculation of the regression; + : early spring measurements; $\triangle$ : June measurements; $\diamond:$ July-September measurements. 
DISSOLVED CARBOHYDRATES IN ESTUARINE ENVIRONMENTS

29
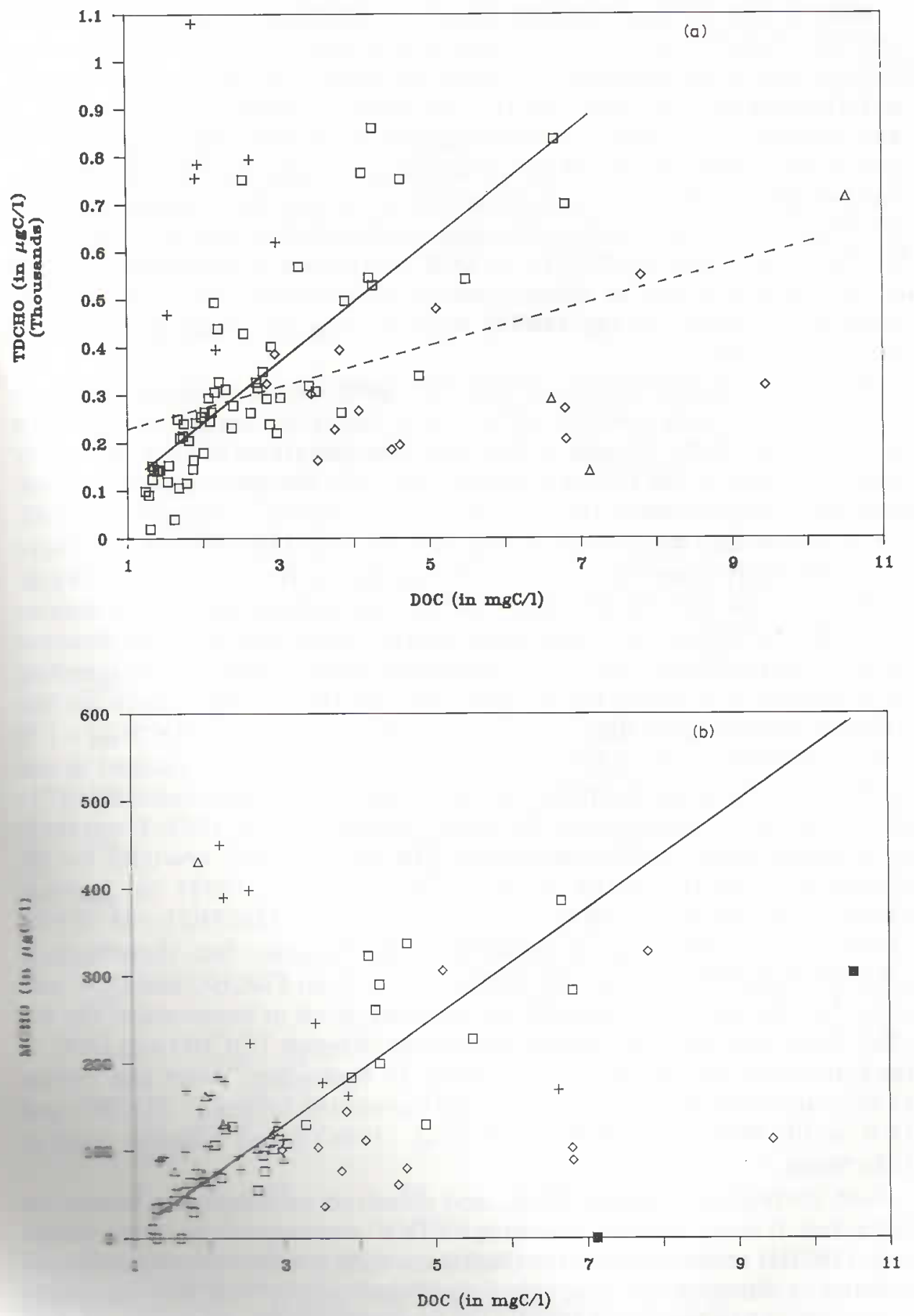
retractory, this result implies that dissolved carbohydrates stould be refractory too. However, we have to recognize that some usable dissolved carbohydrate may be lost, especially for the period preceding fixation i see Methods and Material section). For TDCHO, the probable losses $\left(15-30 \mu \mathrm{g} \mathrm{C}^{-1}\right)$ were low relative to TDCHO concentrations (only two values under $100 \mu \mathrm{g}$ $\mathrm{C}^{-1}$ ), and consequently did not invalidate our result. For $\mathrm{MCHO}$, concentrations were lower and monosaccharides were used more rapidly (Ochiai and Nakajima (1985) measured a glucose degradation rate of $14 \mu \mathrm{g} \mathrm{C} 1^{-1}$ $\mathrm{h}^{-1}$ )); consequently, the MCHO vs. DOC correlation is better than it should be. It is still true that, in autumn-winter, a significant part of the MCHO fraction (measured by the MBTH method) was not made up of usable monosaccharides.

When the biological activity is high, this correlation is no longer observed. For instance, in July and September, most points are under the regression lines (see Fig. 4a,b), because at this time, concentrations of DOC were very high, but those of MCHO or TDCHO were not. On the contrary, in June, there was a large excess of TDCHO (see Fig. 4a), mainly composed of PCHO.

It is noteworthy that similar correlations between TDCHO and DOC have been previously observed in various environments. Burney et al. (1979) reported that $\mathrm{MCHO}, \mathrm{PCHO}$ and TDCHO showed significant correlations $(P<0.01)$ with DOC in a study performed in a large area on the continental shelf of North America and across the North Atlantic Ocean, with sampling at the surface or at depth. For instance, the TDCHO vs. DOC regression line calculated from their data $(r=0.71 ; n=84 ; P<0.001 ;$ [TDCHO] $=170$ $( \pm 20)$ [DOC $]-25( \pm 30))$ is reasonably similar to that obtained in our study. The same group had previously published (Burney and Sieburth, 1977) data collected in Narragansett Bay from February to July 1975. From these data, a good linear correlation between TDCHO and DOC $(r=0.83 ; n=20$; $P<0.001 ; \quad[\mathrm{TDCHO}]=115( \pm 20) \quad[\mathrm{DOC}]-70( \pm 120))$ or between $\mathrm{MCHO}$ and DOC $(r=0.87 ; n=20 ; \quad P<0.001 ; \quad[\mathrm{MCHO}]=48 \quad( \pm 6)$ [DOC] $-62( \pm 45))$ can be deduced. In the Sargasso Sea, these authors (Burney et al, 1981b), observed similarities between TDCHO and DOC patterns, but unfortunately they did not give any detail or explanation. On the other hand, they did not find any correlation between TDCHO and DOC in the Caribbean Sea (Dumey et al., 1982). In freshwater, Sweet and Perdue (1983) also noticed "a moderately good correlation between" TDCHO and DOC in the Williamson River. Satoh et al. (1986) found a similar result in Lake Suwa.

Such correlations between DOC and dissolved carbohydrates cannot be fortuitous. It would be very surprising for DOC and biogenic and even refractory TDCHO to follow similar evolutions in such a variety of environments. A better explanation could be that a significant part of TDCHO (especially in periods of low biological activity) is in a refractory form associated with 

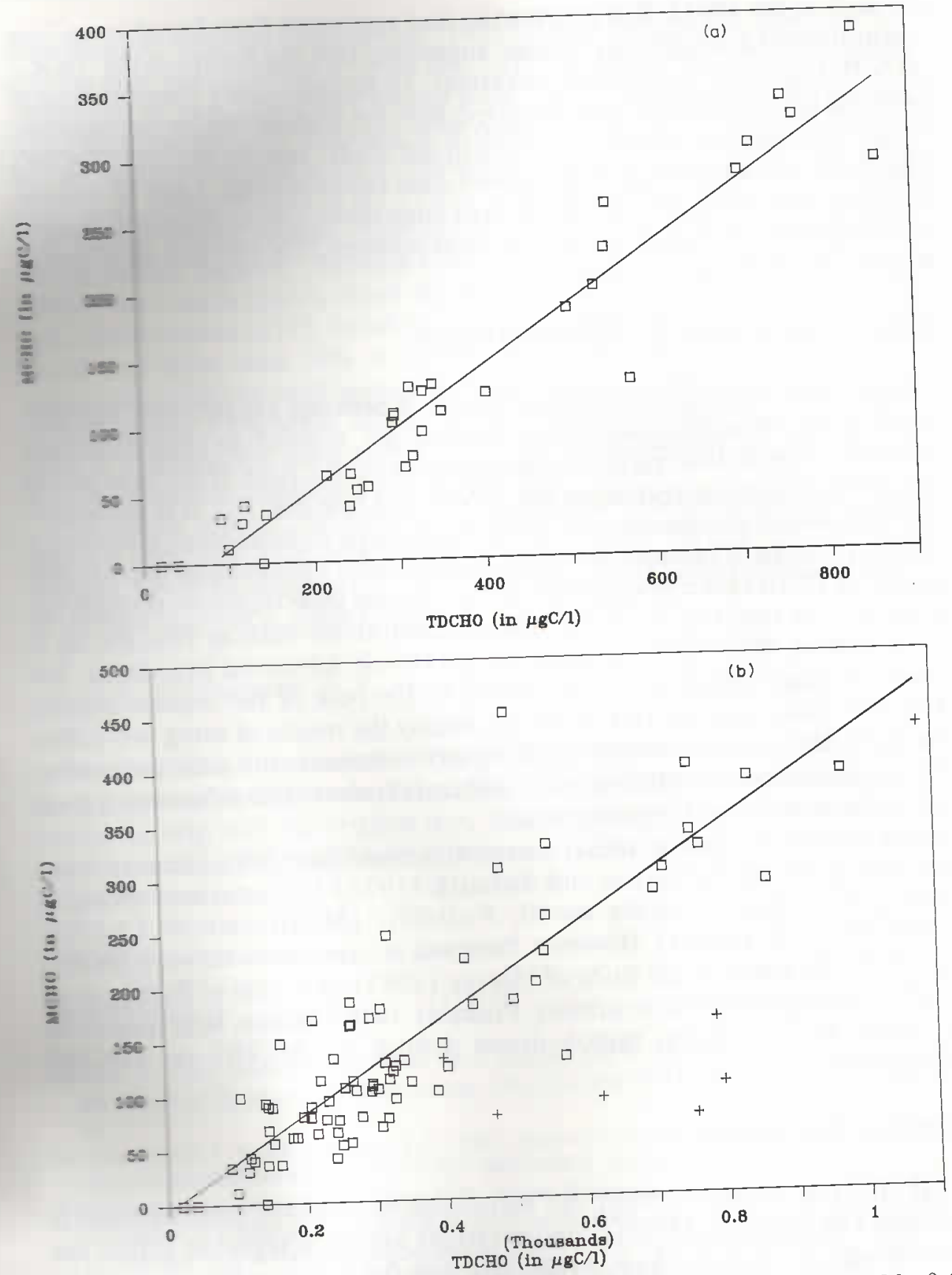

Fig. 5. The direct relationship of $\mathrm{MCHO}$ to TDCHO. (a) in autumn-winter: [MCHO] $=0.44$ (b) For overall points except $1=0.02)[\mathrm{TDCHO}]-35(\mathrm{MCHO}]=0.44( \pm 0.03) \quad[\mathrm{TDCHO}]-5 \quad( \pm 50) \quad(r=0.87 ; n=77$; those for 
the bulk of the DOM. It is noteworthy that regression lines found in various environments are relatively similar, suggesting that the nature of the ' $\mathrm{DOC}$ TDCHO complex' is relatively unvariant. To this refractory fraction, freshly excreted polysaccharides may be added; they are responsible for the non-conservative behaviour observed in June in our study, and for the diel TDCHO variations often observed and reported (see Introduction). Lack of correlation may also result from production of large quantities of dissolved organic substances which distupt the relationship between TDCHO and DOC (as in summer in the present study).

\section{Relationship between $\mathrm{MCHO}$ and TDCHO}

There was an excellent linear relationship between $\mathrm{MCHO}$ and TDCHO (see Fig. 5a) in autumn and winter. Surprisingly, most of the other points are relatively close to this regression line except those for June. If the June points are ignored, a similar regression line is obtained (see Fig. 5b). It is inconceivable that truly free monosaccharides and polymeric carbohydrates follow such similar patterns of release and uptake. It also seems unbelievable that $\mathrm{MCHO}$ as well as PCHO are not significantly used during their transport through the estuary (2-4 days) at relatively high concentrations such as 100-200 $\mu \mathrm{g} \mathrm{C}$ $1^{-1}$ ). Indeed, this result confirms the previously advanced hypothesis, because, if most carbohydrates are linked to the bulk of the organic matter, TDCHO values and $\mathrm{MCHO}$ values are simply the results of using two different methods (with and without hydrolysis) to measure the same parameter: the concentration of carbohydrates (and carbohydrate-like substances) present in the transformed organic matter.

It is noteworthy that a similar correlation could have been obtained from It is noteworthy that a similar corred sing
the data collected by Burney and Sieburth $(1977)$ in winter and spring in
Narragansett Bay $(r=0.96 ; n=20 ; P<0.001 ;[\mathrm{MCHO}]=0.39( \pm 0.03)$ [TDCHO] $-20( \pm 25))$. However, there was no correlation between MCHO and TDCHO either in the study of Harvey (1983) or in that of Burney et al. (1979), both performed in summer. Probably, in this season, large quantities of newly biosynthesized carbohydrates disturb the MCHO vs. TDCHO relationship.

\section{GENERAL DISCUSSION}

As noted in the Introduction, our knowledge on dissolved carbohydrates is limited. For instance, MCHO concentrations are often reported within the $50-100 \mu \mathrm{g} \mathrm{C} 1^{-1}$ range, which is relatively high for easily usable compounds. Glucose, the most dominant monosaccharide constituent of the MCHO fraction (Mopper et al., 1980), is measured by chemical methods at much higher concentrations than those expected from the $K_{\mathrm{t}}+S_{\mathrm{n}}$ values determined by mi- 
crobiological methods (Gocke et al., 1981). These last workers supposed that glucose may exist either in a "truly free form" usable by heterotrophic microorganisms or in a "reversibly bound form" that is unusable. This last form could be associated, for instance, with organic compounds. Ind (HS) (Werknown that carbohydrates are a constituent of melanoidin theory even suggests shaw et al., 1981; Wilson et al., 1983). The metrates. This theory has recently rethat HS are mainly formed from (Benzing-Purdie and Ripmeester, 1983; Ikan et al., ceived further support (Benzing the nature and the strength of bonds which 1986 ), but little is kno In fulvic acid (FA), De Haan and De Boer (1978) link carbohydre that more than $50 \%$ of carbohydrates were not associated, or were loosely associated by weak acid-labile bonds to FA. Sweet and Perdue (1982) identified only $2.8 \%$ of the aquatic humus carbon as sugar carbon. Probably, there is a continuum between sugars loosely associated to HS and carbohydrate-like entities completely included in HS.

Our results support the view that a signific matter. To this TDCHO bound drates is associated with the refarbohydrates may be added, but the turnover of the new fraction is much quicker.

\section{ACKNOWLEDGEMENTS}

We thank Dr. P. le Corre for fruitful discussion and Professor P. Courtot For his interest in this work. The authors are particularly indebted to R. SiSor his interest in this work. The authors are particul to A. Abiven for typing
borski for help with the original text. We are grateful to
the manuscript. The assistance of the crew of 'Saint Anne du Portzic' is also achovledged.

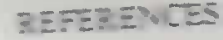

Amino: A I5: Mesure de la salinité. In: A. Aminot and M. Chaussepied (Editors), Manuel des Araby ses Com:cicues en Milieu Marin. CNEXO-BNDO/Documentation, Brest. pp. 45. 1983. Melanoidins and soil organic matter: evidence 62. of strong similarities revealed by ${ }^{13}$ C CP-MAS Ner-Reimer, E. and Siebers. D.. 1979. The de-

Brockmann, U.H., Eberlein, K.. Junge, H.D., Mn in outdoor tank with nutrient-poor sea water. velopment of a natural plankton poputes and amino acids. Mar. Ecol..Prog. Ser.. 1: 283-291. II. Changes in dissolved carbohydrates and amite accumulation in coastai water of South Flor-

Burney, C.M., 1986a. Diel dissolved carbohydrate accum Sci.. 23: 197-203. ida, Bermuda and Oahu. Estuarine Coastal Shef Scis dissolved carbohydrates in offshore

Burney. C.M. 1986b. Bacterial utilization of total waters. Limnol. Oceanogr.. 3I (2). 107- D.sscived carbohy drates in seawater. II. A spectro-

Bumey. C.M. and Sieburth. J. Mc... 
photometric procedure for total carbohydrate analysis and polysaccharide estimation. Mar. Chem., 5: 15-28.

Burney, C.M., Johnson, K.M., Lavoie, D.M. and Sieburth, J. McN., 1979. Dissolved carbohydrate and microbial ATP in the North Atlantic: concentrations and interactions. Deep-Sea Res., 26A: 1267-1290.

Burney, C.M., Johnson, K.M. and Sieburth, J. McN., 1981a. Diel flux of dissolved carbohydrate in a salt marsh and a simulated estuarine ecosystem. Mar. Biol., 63: 175-187.

Burney, C.M., Davis, P.G., Johnson, K.M. and Sieburth, J. McN., 1981b. Dependence of dissolved carbohydrate concentrations upon small scale nanoplankton and bacterioplankton distributions in the Western Sargasso Sea. Mar. Biol., 65: 289-296.

Burney, C.M., Davis, P.G., Johnson, K.M. and Sieburth, J. McN., 1982. Diel relationships of microbial trophic groups and in situ dissolved carbohydrate dynamics in the Caribbean Sea. Mar. Biol., 67: 311-322.

Dawson, R. and Liebezeit, G., 1981a. The analytical methods for the characterization of organics in sea-water. In: E.K. Duursma and R. Dawson (Editors), Marine Organic Chemistry. Elsevier, Amsterdam, pp. 445-496.

Dawson, R. and Liebezeit, G., 1981 b. Determination of amino acids and carbohydrates. In: K. Grasshoff, M. Ehrhardt and K. Kremling (Editors), Methods of Seawater Analysis, 2nd edn. Verlag Chemie, Weinheim, pp. 319-346.

De Haan, H. and de Boer, T., 1978. A study of the possible interactions between fulvic acids, amino acids and carbohydrates from Tjeukemeer, based on gel filtration at $\mathrm{pH} 7.0$. Water Res., 12: 1035-1040.

Eberlein, K., Brockmann, U.H., Hammer, K.D., Kattner, G. and Laake, M., 1983. Total dissolved carbohydrates in an enclosure experiment with unialgal Skeletonema costatum culture. Mar. Ecol., Prog. Ser., 14: 45-58.

Gocke, K., Dawson, R. and Liebezeit, G., 1981. Availability of dissolved free glucose to heterotrophic microorganisms. Mar. Biol., 62: 209-216.

Harvey, G.R., 1983. Dissolved carbohydrates in the New York Bight and the variability of marine organic matter. Mar. Chem., 12: 333-339.

Ikan, R., Ioselis, P., Rubinsztain, Y., Aizenshtqt, Z., Pugmire, R., Anderson, L.L. and Ishiwatari, R., 1986. Carbohydrate origin of humic substances. Naturwissenschaften, 73: 150-151.

Ittekkot, V., 1982. Variations of dissolved organic matter during a plankton bloom: qualitative aspects based on sugar and amino acid analyses. Mar. Chem., 11: 143-158.

Ittekkot, V., Brockmann, U.,Michaelis, W. and Degens, E.T., 1981. Dissolved free and combined carbohydrates during a phytoplankton bloom in the Northern North Sea. Mar. Ecol., Prog. Ser., 4: 299-305.

Johnson, K. and Sieburth, J. McN., 1977. Dissolved carbohydrates in seawater, I. A precise spectrophotometric analysis for monosaccharides. Mar. Chem., 5: 1-13.

l'Yavanc, J., 1984. Etude hydrologique de l'estuaire de l'Elorn. Rapport IFREMER-Brest, 29 pp.

Liebezeit, G. and Dawson, R., 1982. The analysis of natural organic compounds in seawater. Kontakte (Merck), No. 2: 19-28.

Lorenzen, C.J., 1967. Determination of chlorophyll and phaeopigments: spectrophotometric equations. Limnol. Oceanogr., 12: 343-346.

Mantoura, R.F.C. and Llewellyn, C.A., 1983. The rapid determination of algal chlorophyll and carotenoid pigments and their breakdown products in natural water by reverse-phase highperformance liquid chromatography. Anal. Chim. Acta, 151:297-314.

Mopper, K., 1980. Carbohydrates in the marine environment: recent developments. In: Biogéochimie de la Matière Organique à l'Interface Eau-Sédiment Marin. Colloques Internationaux du CNRS, No. 293. Editions du CNRS, Paris, pp. 71-80. 
Mopper, K., Dawson, R., Liebezeit, G. and Ittekkot, V., 1980. The monosaccharide spectra of natural waters. Mar. Chem., 10: 55-66.

Myklestad. S.. 1977. Production of carbohydrates by marine planktonic diatoms. II. Influence of the $\mathrm{N} / \mathrm{P}$ ratio in the growth medium on the assimilation ratio, growth rate, and production of cellular and extracellular carbohydrates by Chaetoceros affinis var. Willei (Gran) Hustedt and Skeletonoma costatum (Grev.) Cleve. J. Exp. Mar. Biol. Ecol., 29: 161-179.

Noureddin. S.. Chevolot. L., Senior, W. and Courtot, P., 1987. Etude des substances humiques dissoutes dans la rade de Brest. Océanis, 13: 395-403.

Ochiai. M. and Nakajima, T., 1985. Decomposition of organic matter extracted from sessile microbes. Verh. Int. Verein. Limnol., 22: 2744-2748.

Ochiai, M.. Nakajima. T. and Hanya, T., 1980. Chemical composition of labile fractions in DOM. Hydrobiologia, 71: 95-97.

Sakugawa, J. and Handa, N., 1985. Chemical studies on dissolved carbohydrates in the water samples collected from the North Pacific and Bering Sea. Oceanol. Acta, 8(2): 185-196.

Satoh, Y.. Hayashi. H., Nakamoto, N. and Okino, T., 1986. Regulating factors of the concentration of dissolved carbohydrates in a central water column of Lake Suwa, Japan. Arch. Hydrobiol.. 105(3): 299-319.

Senior, W.. 1986. Etude de la matière organique dans l'estuaire de l'Elorn. Thèse de Doctorat, Université de Bretagne Occidentale, $158 \mathrm{pp}$.

Senior. W.. Chevolot, L., Noureddin, S. and Courtot, P., 1987. Evolution saisonnière de la matière organique dissoute dans l'estuaire de l'Elorn. Les carbohydrates. Océanis, 13: 413-426.

Sumitra. V.. Joseph, K., Easterson, D.C.V. and Balachandran, V.K., 1972. Studies on dissolved carbohydrate content (DCHO) in a tropical estuary. J. Mar. Biol. India, 14: 864-866.

Sweet. M.S. and Perdue, E.M., 1982. Concentration and speciation of dissolved sugars in river water. Environ. Sci. Technol., 16: 692-698.

Walsh. G.E., 1965. Studies on dissolved carbohydrate in Cape Cod waters. II. Diurnal fluctuation in Oyster Pond. Limnol. Oceanogr., 10: 577-582.

Wershaw, R.L., Mikita, M.A. and Steelink, C., 1981. Direct ${ }^{13} \mathrm{C}$ NMR evidence for carbohydrate moieties in fulvic acids. Environ. Sci. Technol., 15: 1461-1463.

F lsoc. M.A., Gillam, A.H. and Collin, P.J., 1983. Analysis of the structure of dissolved marine - substances and their phytoplanktonic precursors by ${ }^{1} \mathrm{H}$ and ${ }^{13} \mathrm{C}$ nuclear magnetic resane. Chem. Geol., 40: 187-201. 